\title{
27. CORRELATION OF NATURAL GAS ZONATION AND CARBONATE DIAGENESIS IN TERTIARY SEDIMENTS FROM THE NORTH-WEST ATLANTIC
}

\author{
Yves Lancelot $^{1}$, Laboratoire de Geologie Dynamique Universite de Paris-VI, Paris, France \\ and \\ J. I. Ewing, Lamont-Doherty Geological Observatory, Palisades, New York
}

\section{INTRODUCTION}

Tertiary sediments recovered from Sites 102, 103, 104 and 106 during Leg 11 of the Deep Sea Drilling Project (Figure 1) consist of dark-gray hemipelagic muds and are rich in natural gas. The presence of gas in these sediments may be related, either directly or indirectly, to peculiarities in seismic properties and in mineralogical composition.

The physiochemical state of the gases in the sediments can have an effect on sound velocities (Stoll et al., 1971) and could be responsible for the presence on the seismic records from the Blake-Bahama Outer Ridge of a seismic reflector, parallel to the seafloor topography that cuts through the "bedding-plane" reflectors (Figure 2). This reflector, called reflector $\mathrm{Y}$ by Markl et al. (1970), is discussed by Ewing and Hollister elsewhere in this volume. Alternatively, environmental conditions that result in the production of large amounts of natural gas may also produce a mineralogical zonation that could explain reflector Y. Whether there is a direct relationship between the presence of the gas, the reflector, and the diagenetic processes that have led to the distribution of carbonate minerals observed in the sediments is not clear, but it is noteworthy that the observed conditions seem to be related to regions where rapid deposition of terrigenous sediment has occurred.

Few opportunities exist to study these effects directly because in rocks outcropping on land the gas, if ever present at all, has escaped, and relations between its presence and the production of particular structures and diagenetic minerals have rarely been attempted. This was noted by P. E. Cloud (1960) who pointed out that "despite the frequency with which stagnant basins and anaerobic conditions are invoked in geologic reconstruction, and although it seems instinctively probable that the effects of gas on sedimentary rocks should be both widespread and recognizable, little has been published that deals with specific gas effects in the stratigraphic column." In recent marine sediments

\footnotetext{
${ }^{1}$ The author gratefully acknowledges financial support for this work provided by CNEXO (Centre National pour l'Exploitation des Oceans, France) under contracts 69/62, $69 / 117,70 / 150$ and $71 / 253$.
}

obtained by piston coring, the gas content is usually too low to produce significant effects and deep sea drilling provides an exceptional opportunity to study such effects.

Obviously, a more extensive study of the Leg 11 sediments will be necessary to reach definite conclusions but it appears important to the writers, even at this preliminary stage of the investigations, to point out observations that may bear directly on fundamental problems of diagenesis in the sediments.

\section{THE GAS}

The presence of large amounts of gas in the sediments from the entire sequence sampled at Sites 102, 103, 104 and 106 was observed during the removal of the plastic liners from the core barrels. In many cases gas expansion was strong enough to cause extrusion of the sediments from the liner and produce sectioning of the cores (see Site Reports in this volume). Although the main degassing occurred as soon as the core barrels were opened, the cores continued to produce some gas for periods of one to two hours.

Only qualitative determinations of the gases and semiquantitative estimates of their relative amounts were performed aboard the ship. They indicated the presence of dominant $\mathrm{CH}_{4}$, some $\mathrm{CO}_{2}$, occasional $\mathrm{H}_{2} \mathrm{~S}$ (particularly at Site 104), and traces of $\mathrm{C}_{2} \mathrm{H}_{6}$.

Observations of unusual sound velocities in the sediments (see discussion in Ewing and Hollister, this volume) and experimental work conducted at Lamont-Doherty Geological Observatory (Stoll et al., 1971) led to the conclusion that in most of the interval where gassy sediments were recovered, some of the $\mathrm{CH}_{4}$ may have been in situ in the form of hydrate (often referred to as clathrate). In the hydrate structure, gas molecules are physically (but not chemically) bonded to water molecules in an ice-like arrangement. The formation of hydrates is controlled by pressure, temperature and the amounts of gas and water available. Theoretically, provided the partial pressure of the gas is sufficient to account for the presence of undissolved gas, clathrates could be present in the sediment section at Sites 102, 103 and 104, from the sea floor to a subbottom depth of about 600 


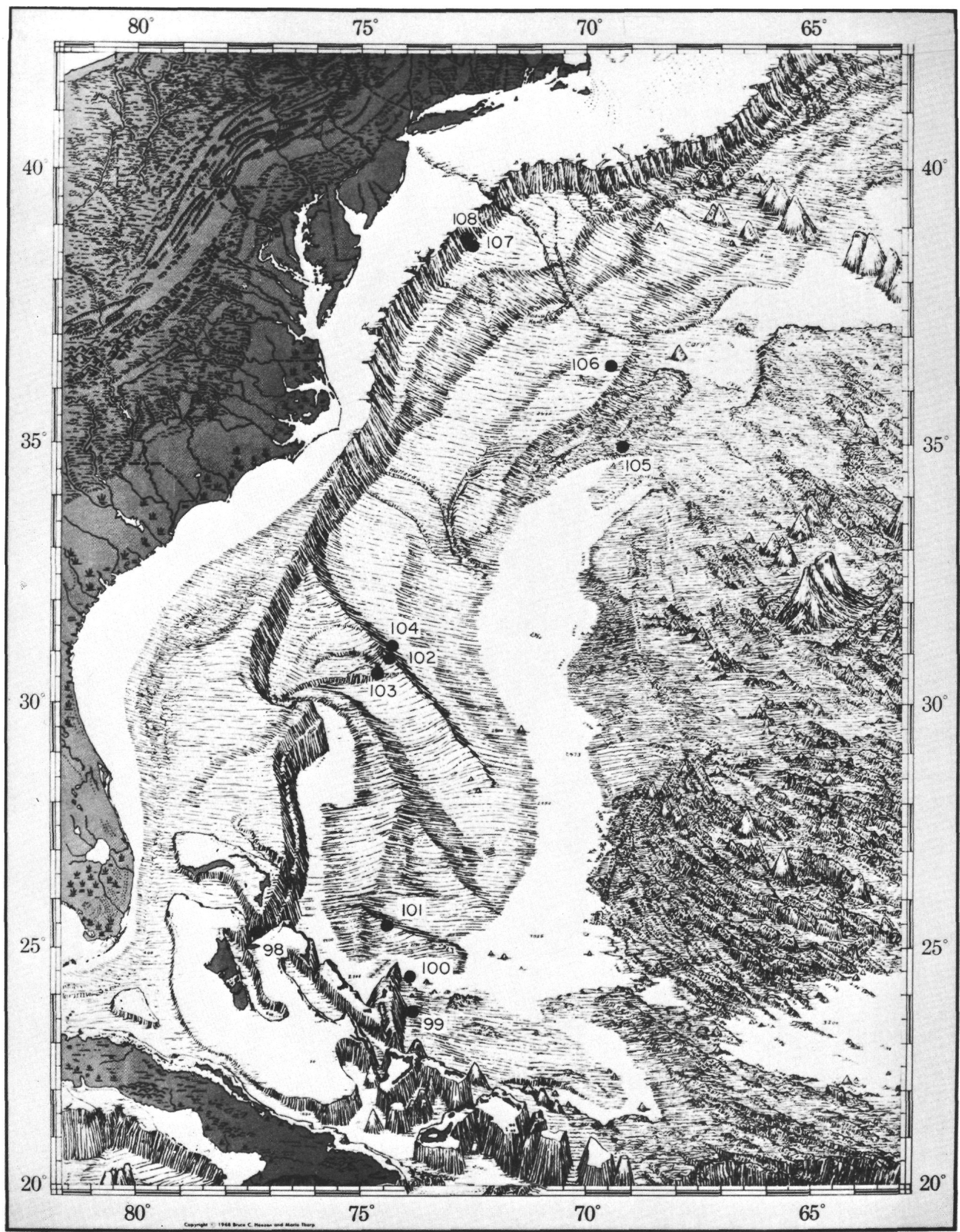

Figure 1. Location of the drilling sites (physiographic diagram from B. C. Heezen and M. Tharp, 1968) 

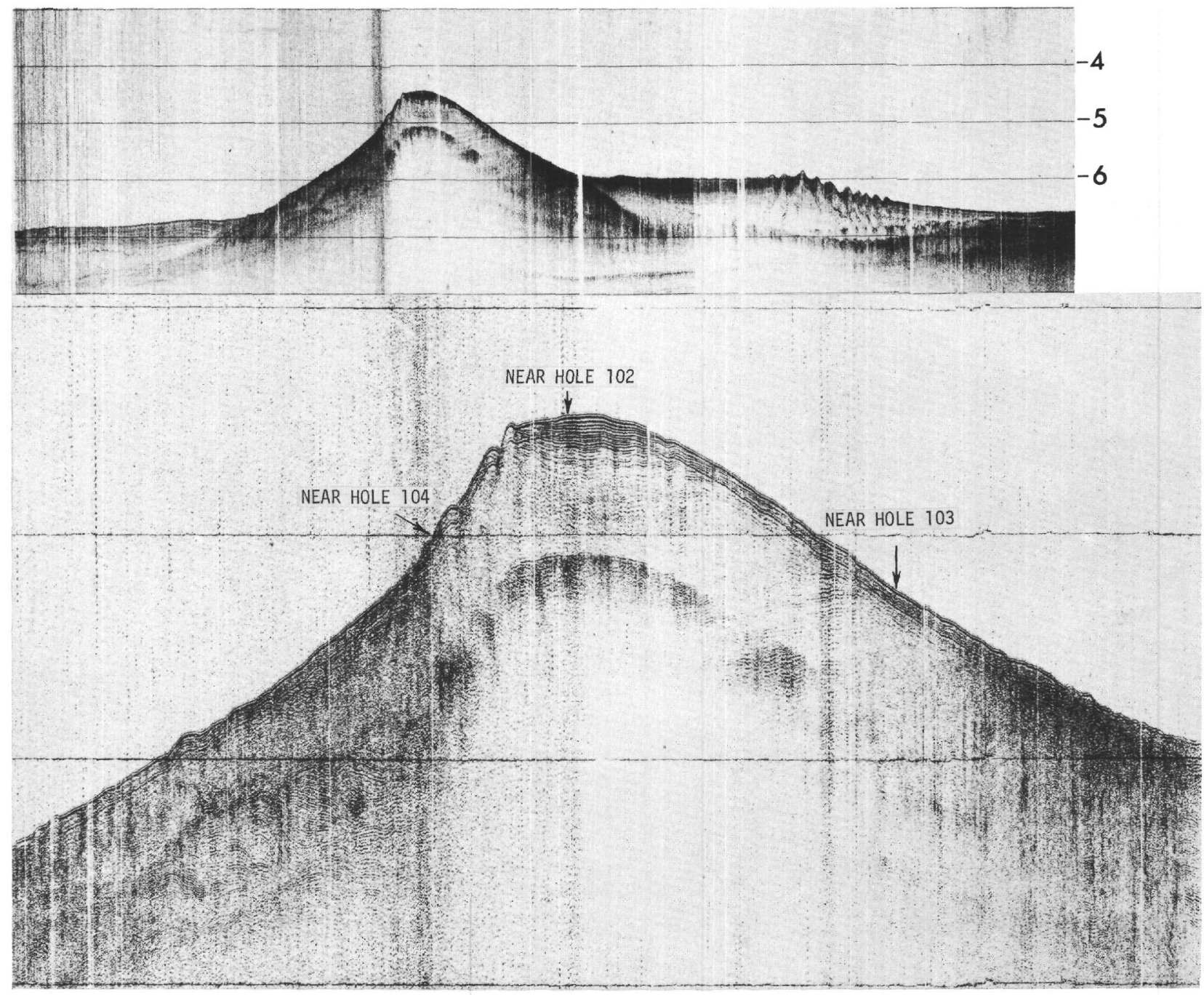

Figure 2. Vema 21 seismic profiler section across the Blake-Bahama Outer Ridge (crestal region expanded below). Note the reflector parallel to the sea floor, cutting through the bedding-plane reflectors.

meters (Ewing and Hollister, this volume). Beneath that depth, an excess of undissolved free gas could be present. In fact, it is difficult to know precisely the vertical extent of the clathrate zone, as among the variables involved only the in situ pressure can be calculated with relatively good precision. Temperature values can only be inferred from extrapolating the geothermal gradient measured in the upper layers of similar sediments, as no temperature measurements have been successful yet in the deep sea bore holes. The relative amounts of gas present in the different layers is totally unknown. The main source of gas probably lies in the deeper parts of the sedimentary section, and accumulation at certain levels may be caused by a substantial upward migration of the gas. If a large amount of free gas migrates toward the sea floor, it will reach a level at which conditions are favorable for clathrate formation, and accumulate there. It is improbable, then, that the surficial layers would contain enough gas to form clathrates. It might be speculated that in some cases the clathrate zone could even form a solid cap, restricting upward diffusion and producing a relatively high concentration of free gas in the underlying sediments.

From these considerations a "gas stratification" for methane in the sedimentary section could be:

(1) Surficial zone, with relatively small amounts of dissolved gas and no clathrates.

(2) Intermediate zone, with gas dissolved and in the form of clathrates.

(3) Deep zone with dissolved and free gas. 
This zonation, being largely temperature controlled, should remain approximately parallel to the sea floor and, as discussed by Ewing and Hollister, might account for reflector Y. For reasons mentioned above, the respective thicknesses of these zones cannot be directly defined. The following discussion attempts to correlate the observations made on sediments and interstitial waters with the postulated model of gas zonation.

\section{SEDIMENTOLOGICAL OBSERVATIONS}

The gas-rich sediments are described in detail in the separate reports for Sites 102, 103, 104 and 106 in this volume. They consist of hemipelagic muds having an average carbonate content ranging generally from 10 to 20 per cent. Much higher values are recorded in some samples; they correspond to local concentrations (lenses, nodules, and layers) of calcite, dolomite, and siderite. The nature of the carbonate fraction was determined primarily by microscopic examination of smear slides aboard the ship (Lancelot et al., this volume) and additional data were provided by X-ray determinations obtained from shore-based laboratories (Zemmels et al., this volume). Detailed investigations performed on the interstitial waters from these sediments are given in Presley and Kaplan, and Sayles et al. (this volume). Selected results are summarized in Figure 3.

The carbonates in the three holes follow definitely similar trends. The top part of the section (down to 200-400 meters below bottom) contains relatively abundant calcite and dolomite with occasional siderite, while the deeper part shows a generally increasing amount of siderite. This zonation is highly time-transgressive in Holes 102, 103 and 104 and remains roughly parallel to the sea-floor topography. It may therefore be directly related to diagenetic processes in which pressure and temperature should play a dominant role.

Calcite is present in two forms: biogenic (foraminifera and nannofossil tests) and apparently authigenic (concretions of micritic limestone and microscopic

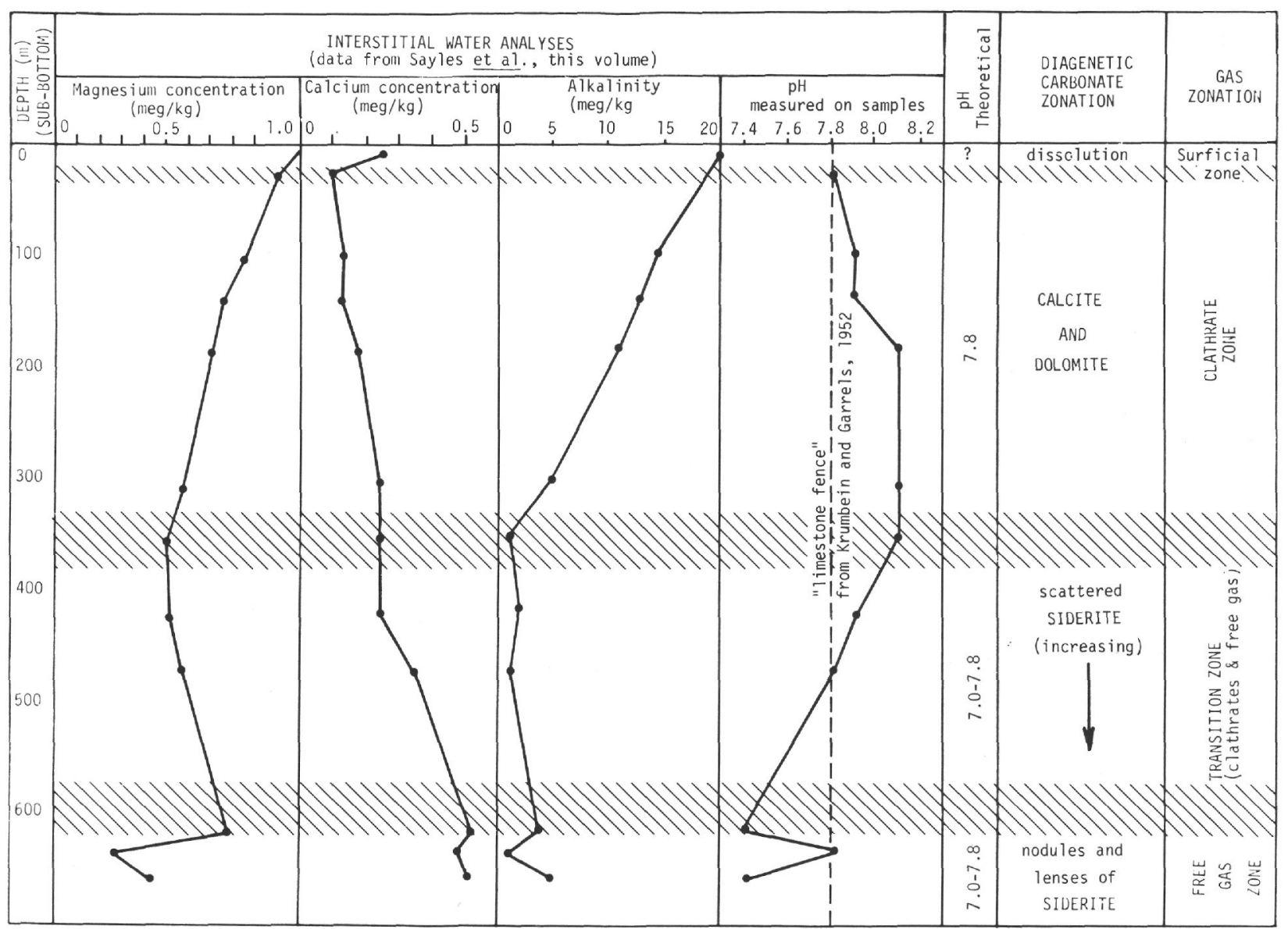

Figure 3. Comparison of interstitial water data (Sayles et al., this volume), carbonate composition and postulated gas zonation at Site 102. 
calcareous aggregates). Dolomite appears as dispersed, well-crystallized rhombs. It is occasionally concentrated in some layers where its distribution shows a negative correlation with that of the biogenic calcite (for example, as in Hole 103, Core 2, Sections 5 and 6). It is probable that the diagenetic calcite and dolomite are derived from the biogenic calcite.

Siderite appears first as isolated well-crystallized rhombs scattered in the sediments, and deeper in the holes it tends to be concentrated in lenses and nodules. At Site 104, a large nodule or layer of fine-grained ankerite was found at the bottom of the hole. It degassed for several hours after it was brought to the surface and split. At Site 106, in well-indurated sediments, siderite is frequently concentrated along vertical fractures (Figure 4), and occurs as a filling of burrow-like structures. These structures may be interpreted as the result of gas migration in the sediments and can be compared to those described by Cloud (1960). Similar structures were also observed in the lower parts of Holes 102 and 104, but in most cases the disturbances caused by gas expansion in the unlithified sediments probably destroyed them.

Data from the analyses of the interstitial waters show a zonation parallel to the mineralogical one. Alkalinity and $p \mathrm{H}$ values as well as the distribution of magnesium and calcium are of special interest. Relatively high $p \mathrm{H}$ values are found in the calcite-dolomite zone. The $p \mathrm{H}$ decreases with depth in correspondence with the disappearance of these minerals and the increasing abundance of siderite. Alkalinity is high, but decreases regularly in the calcite-dolomite zone, and is very low in the siderite zone. Magnesium and calcium are both strongly depleted at depth in the interstitial waters from Sites 102, 103 and 104. Their distribution is discussed in Sayles et al. (this volume). These authors point out that magnesium depletion exceeds that attributable to the alteration of montmorillonite (formation of magnesium-montmorillonite by replacement of iron by magnesium during the reduction of sulfate $\left(\mathrm{SO}_{4}\right)$ and formation of pyrite). They could not observe any good correlation between magnesium depletion and formation of dolomite from the available X-ray data, but this might be the result of sample spacing, as dolomite is often concentrated in some layers that were not sampled for X-ray analysis. Nevertheless, dolomite (often calcium-rich) is regularly reported in the upper 300 meters of sediments at Sites 102, 103 and 104 (see discussion by J. C. Hathaway in Zemmels et al., this volume). Thus dolomite formation can, at least in part, still explain the overall magnesium depletion. The excessively high $\mathrm{Ca} / \mathrm{Mg}$ ratio values found in the interstitial waters do not fit this explanation, but the source of the excess of calcium can be found in the dissolution of biogenic calcite. The negative correlation observed in the distribution of biogenic calcite and dolomite at Site 103 (Core 2,
Sections 5 and 6) supports this hypothesis. Additional calcium is released during the formation of siderite in the deeper parts of the sedimentary section. Some evidence has been recorded in older sediments recovered during Leg 11, showing that siderite can be derived directly from biogenic calcite and in some cases from dolomite. At Site 101, for example, some of the microfossils were replaced by siderite, and in one sample a twinned overgrowth of siderite was observed on a dolomite rhomb (see Site Reports). Calcium ions released at depth can probably diffuse upward in the entire section and can play an important role in the precipitation of calcite and dolomite in the upper parts of the section (R. M. Garrels, personal communication).

\section{GEOCHEMICAL OBSERVATIONS}

The following distribution of $\mathrm{Eh}$ and $p \mathrm{H}$ values was observed in the sections studied.

Eh: Occurrence of gas, pyrite, siderite, and organic matter is indicative of reducing conditions in the sediments, and the Eh can be considered to be negative in most of the section. This reducing environment probably was not caused by bottom water stagnation, as strong currents are believed to have prevailed during the deposition of the Tertiary hemipelagic muds on the continental rise (Site 106) and on the Blake-Bahama Outer Ridge (Sites 102, 103 and 104) (see discussion by Ewing and Hollister, this volume). The very high rates of sedimentation (up to $20 \mathrm{~cm} / 1000 \mathrm{yrs}$ ) were probably instrumental in maintaining anaerobic conditions very close to the sediment/water interface.

$p \mathrm{H}$ : Distribution of $p \mathrm{H}$ values in interstitial water shows a substantial decrease toward the deeper parts of the sediment section.

\section{DISCUSSION}

A schematic model can be drawn showing correlations between the mineralogical composition of the carbonate fraction in the sediments, results of interstitial waters analyses, and the postulated gas zonation. It is based mainly on the classical data from Krumbein and Garrels (1952) and from Theodorovitch (1946, 1947 and 1954) who have defined precisely the distribution of authigenic carbonates with respect to $\mathrm{Eh} / p \mathrm{H}$ environmental conditions in sedimentary rocks.

We re-emphasize that although the zonation of carbonate mineralogy, interstitial water, and gas environment are probably parallel, it is difficult to know what is cause and what is effect, if indeed, there is a direct relationship. 


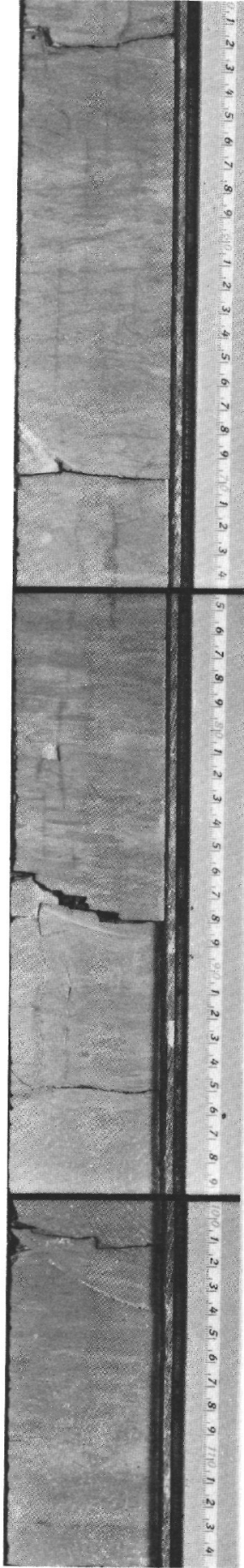

$106 \mathrm{~B}-5-5$

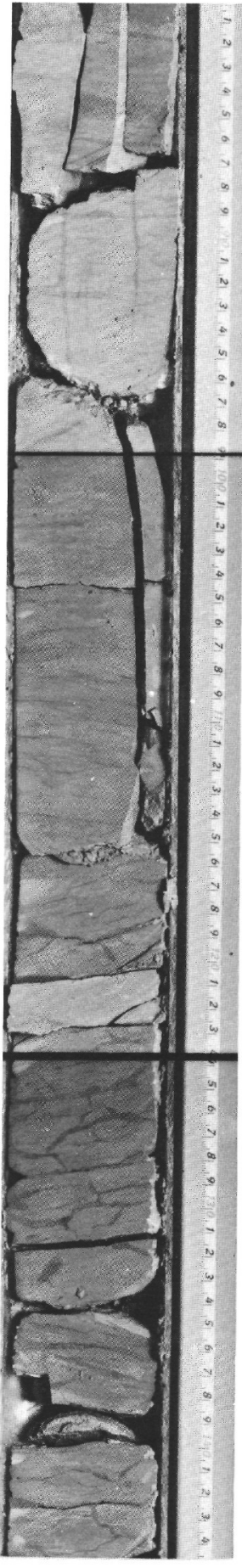

$106 \mathrm{~B}-5-6$

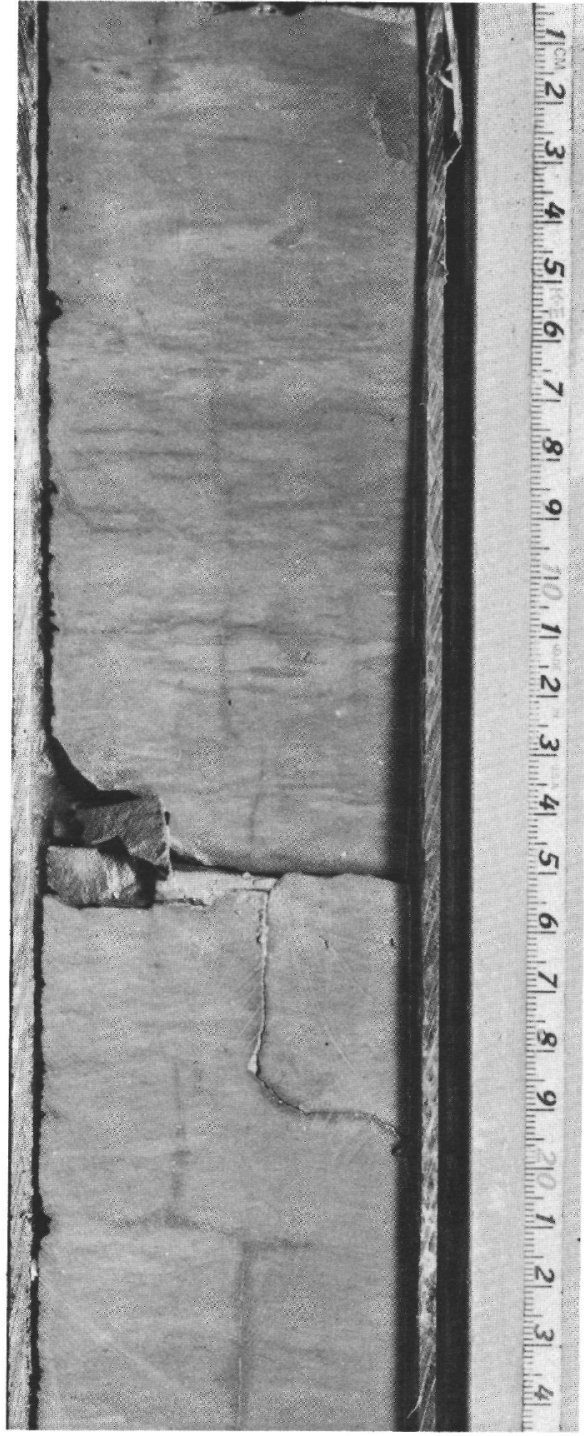

$106 B-5-5$

Figure 4. Sedimentary structures caused by upward gas migration in hemipelagic mud from Site 106. Note the vertical structures lined with light-colored material (siderite); some of these structures are responsible for vertical fractuation in the cores (see 106B-5-6, 80 to $95 \mathrm{~cm}$ ). Note also the "burrow-like" structures in lower half of 106B-5-6. 


\section{Surficial "Normal" Zone}

Biogenic calcite (microfossil tests) is deposited together with organic matter and detrital minerals (dominantly clay minerals). The high sedimentation rate creates a reducing environment where bacterial reduction of sulfate $\left(\mathrm{SO}_{4}\right)$ occurs with production of hydrogen sulfide $\left(\mathrm{H}_{2} \mathrm{~S}\right)$; the $p \mathrm{H}$ drops from that of sea water (approximately 8 ) to lower values. Biogenic calcite is partially dissolved. Near the base of this zone the $p \mathrm{H}$ rises again, possibly because of the consumption of hydrogen sulfide during pyrite formation. Core 2 contains dolomitic fine-grained concretions (see study of special samples by Hathaway in Zemmels et $a l$. , this volume), and a very strong odor of hydrogen sulfide was reported during the opening of the core liner. It is assumed that only small quantities of hydrogen sulfide were present in the sediment, otherwise, no carbonate precipitation would have been possible. Furthermore, the foraminifera observed in the smear slides probably would have been completely dissolved.

The thickness of this zone cannot be easily determined and its lower limit is probably transitional to the clathrate zone. However, the vertical distribution of sulfate $\left(\mathrm{SO}_{4}\right)$ suggests that it does not greatly exceed 25 meters. At greater depths most of the sulfate $\left(\mathrm{SO}_{4}\right)$ has been reduced, and is not found in the interstitial waters (see data in Sayles, et al., this volume).

\section{Clathrate Zone}

Very large amounts of methane are present in the sediments of this zone, and relatively high $p \mathrm{H}$ values are maintained. Calcite precipitates in this zone. The calcium ions are probably provided in part by the dissolved biogenic calcite, but a substantial amount can also be derived from the sideritization occurring in lower layers (upward diffusion of the released calcium ions as suggested by R. M. Garrels, personal communication). Whether dolomite precipitates directly under the same conditions as calcite, or during a later phase, is unknown. It is possible that dolomite precipitation is favored by a relatively high carbon-dioxide pressure following a process similar to that proposed by Cloud (1960, p. 42), but none of our preliminary results allow us to draw conclusions regarding the role of the $\mathrm{CO}_{2}$ partial pressure (see discussions in Krumbein and Garrels, 1952; Fairbridge, 1957; and Garrels and Christ, 1965). The thickness of the clathrate zone deduced from the distribution of calcite and dolomite and from the $p \mathrm{H}$ and alkalinity values (Figure 3), is about 300 to 350 meters at Site 102.

\section{Transition Zone}

The gradual downward increase of the siderite content of the sediment indicates a mineralogical transition zone in the lower part of the methane hydrate zone. In the upper parts of this zone, siderite is at first scattered in the sediments but tends to be more and more concentrated in lenses and concretions downward. The thickness of this zone cannot be directly obtained from the drilling results, and its lower limit is placed at about 500 to 600 meters mainly on theoretical considerations (pressure and temperature).

\section{Free Undissolved Gas Zone}

This zone has the same mineralogical characteristics as the overlying transition zone, with larger amounts of siderite (or ankerite at Site 104) usually concentrated in lenses and nodules.

The zone appears to be controlled by pressure and temperature inasmuch as it tends to remain roughly parallel to sea-floor topography in a given range of water depths. When sediments accumulate, building topographic features like the Blake-Bahama Outer Ridge and the continental rise, the "sideritization front" moves upward accordingly.

\section{REMARKS}

\section{Eh-pH Values}

The authigenic minerals observed in the section can be used as chemical end-members indicative of $\mathrm{Eh}$ and $p \mathrm{H}$ environmental conditions (Krumbein and Garrels, 1952, and Theodorovitch, 1946, 1947 and 1954). The presence of authigenic calcite and dolomite together with organic matter and pyrite places the clathrate zone in the right-hand lower part of the Krumbein and Garrels "fence" diagram (Figure 5) with $p \mathrm{H}$ above 7.8 and Eh lower than about -0.2 . The same results can be obtained using Theodorovitch data that would give for this zone a $p \mathrm{H}$ of 9.0 to 7.8 and a negative Eh ranging from "reducing" to "weakly reducing" (the characteristic minerals would be calcite, dolomite, pyrite and rare siderite). The transition and free-gas zones supposedly would have similar Eh values, but the $p \mathrm{H}$ would drop to values between 7.0 and 7.8 (according to Krumbein and Garrels), and could range from 6.6 to 7.8 (according to Theodorovitch)-the characteristic minerals would be siderite, ankerite, Mg-montmorillonite and some pyrite.

\section{Seismic Implications}

The anomalies in sound velocity caused by the presence of clathrates in the sediments have been analyzed by Stoll et al. (1971 a and 1971 b), and are discussed by Ewing and Hollister (this volume).

The correlation between the abundance of siderite in the sediments (often in hard nodules) and reflector $Y$ on the seismic records is appealing, but can not be definitely established. At Sites 102 and 104 an 


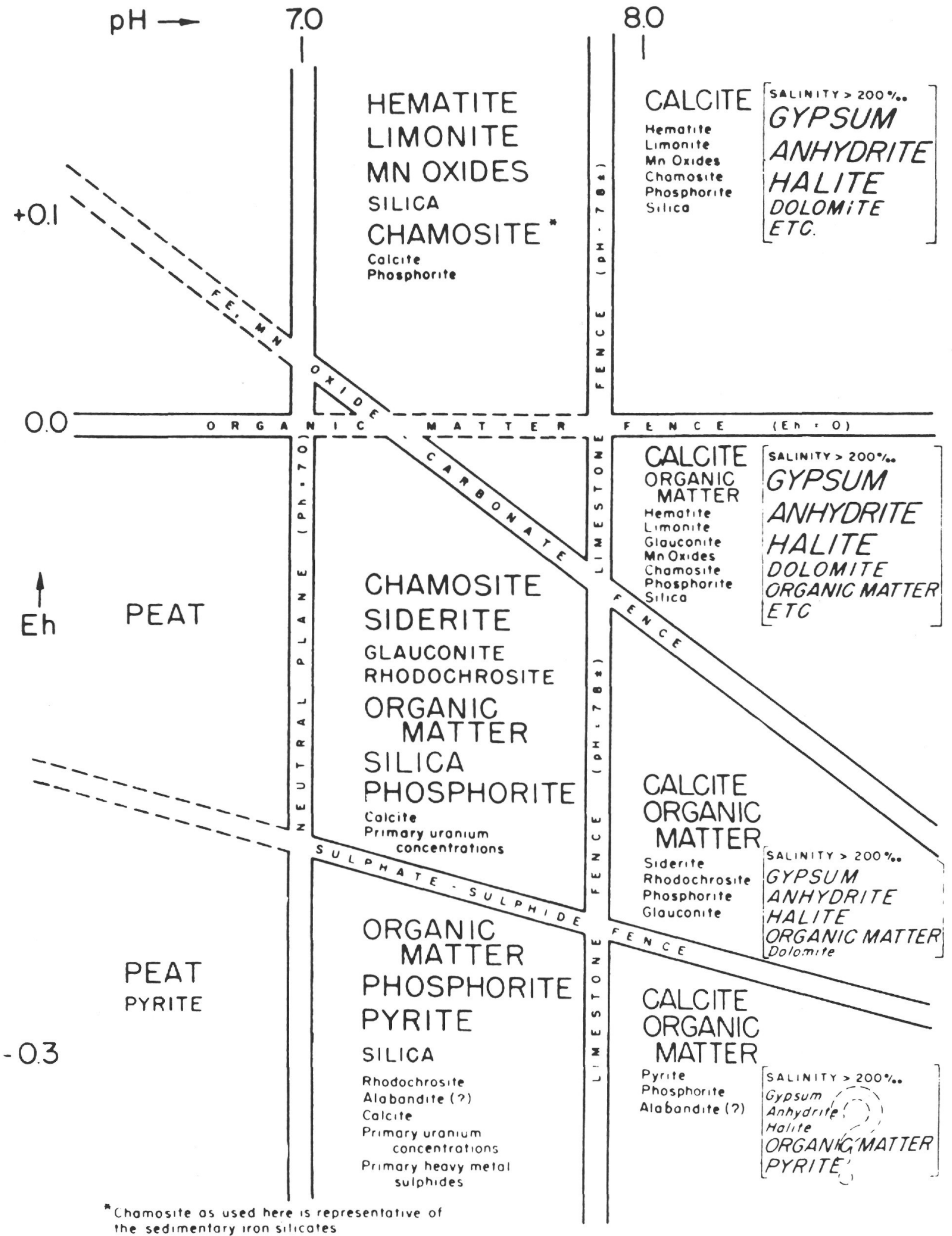

Figure 5. Sedimentary chemical end-member associations in their relations to environmental limitations imposed by selected Eh and $\mathrm{pH}$ values (from Krumbein and Garrels, 1952). 
important drilling break was encountered at a depth corresponding to the reflector (using sound velocities compatible with the presence of clathrates in most of the section). Only at Site 104 did it correspond to a very well-defined lithologic change (hard nodule or layer of ankerite). At Site 102, a general downward increase of siderite nodules and lenses was observed, but there was nothing that seemed to definitely explain both the drilling break and the reflector. The reflector can be the result of impedance mismatch due to the state of the gas in the sediments (see discussion in Ewing and Hollister, this volume), or it can be related to the presence of a discontinuous zone of siderite (or ankerite) nodules. The latter explanation of reflector $Y$ would then be analogous to that of Horizon $\mathrm{A}$ on a strictly physical basis, if the latter is associated with the occurrence of chert nodules.

\section{REFERENCES}

Cloud, P. E., 1960. Gas as a sedimentary and diagenetic agent. Am. J. Sci. 258-A, 35.

Fairbridge, R. W., 1957. The dolomite question. In: Regional Aspects of Carbonate Deposition. R. F. Le Blanc and J. G. Breeding (Eds.) Soc. of Econ. Paleo. and Min. Spec. publ. No. 5.
Garrels, R. M. and Christ, C. L., 1965. Solutions, Minerals and Equilibria. New York (Harper and Row), $450 \mathrm{pp}$.

Krumbein, W. C. and Garrels, R. M., 1952. Origin and classification of chemical sediments in terms of $p \mathrm{H}$ and oxidation-reduction potentials. J. Geol. 60 (1), 1 .

Markl, R. G., Bryan, G. M. and Ewing, J. I., 1970. Structure of the Blake-Bahama Outer Ridge, $J$. Geophys. Res. 75 (24), 4539.

Stoll, R. D., Ewing, J. I. and Bryan, G. M., 1971. Anomalous wave velocities in sediments containing gas hydrates. J. Geophys. Res. 76, 2090.

Theodorovitch, G. I., 1946. Minerals of sedimentary formations as indicators of physical-chemical environment. In: Questions of Mineralogy, Petrography, and Geochemistry. Moscow (Izd. Akad. Nauk. S.S.S.R.).

1947. Sedimentary geochemical facies. Byul, Mosk. Obshchestva Ispytatelei Prirody, Otd. Geol. 22 (1).

1954. Toward question of studying oil-producing formations (source rocks). Byul. Mosk. Obshchestva Ispytatelei Prirody, Otd. Geol. 29 (3), 59. 